\title{
Effect of water activity and storage of tahini on the viability of stressed Salmonella serovars
}

\author{
Tareq OSAILI ${ }^{1,2 *}$ (D), Anas AL-NABULSI², Dima NAZZAL ${ }^{2}$, Murad AL-HOLY $^{3}$, Amin OLAIMAT ${ }^{3}$, Reyad OBAID ${ }^{1}$, \\ Richard HOLLEY ${ }^{4}$
}

\begin{abstract}
Tahini (sesame seed paste) is a low water activity product that has been involved in several salmonellosis outbreaks. The objectives of the study were to examine over a year the impact of $\mathrm{a}_{\mathrm{w}}$ and storage temperature of tahini on the viability of Salmonella serovars previously stressed by drying or heat exposure. Tahini samples adjusted to $\mathrm{a}_{\mathrm{w}}$ values of $0.17,0.35$ and 0.50 were inoculated with a mixed culture containing $10^{6}-10^{7} \mathrm{CFU} / \mathrm{g}$ of 4 serovars of unstressed, desiccation-or heat-stressed Salmonella and stored for up to 12 months at 10 and $25^{\circ} \mathrm{C}$. Generally, viability of stressed or unstressed Salmonella decreased as the storage temperature and time increased or the $\mathrm{a}_{\mathrm{w}}$ of tahini decreased. The survival of stressed or unstressed Salmonella in all samples decreased during storage for up to 12 months by ca. 6.0 and $3.3 \log _{10} \mathrm{CFU} / \mathrm{g}$, respectively. Exposing Salmonella to heat stress had no significant effect on survival in tahini, while desiccation stress significantly decreased survival during storage, especially at $25^{\circ} \mathrm{C}$ in low $\mathrm{a}_{\mathrm{w}}$ tahini.
\end{abstract}

Keywords: tahini safety; water activity; Salmonella; bacterial stresses; storage.

Practical Application: This study indicates that Salmonella serovars can survive in tahini for as long as 12 months. Survival of Salmonella in tahini decreased as storage time and temperature increased and as the $\mathrm{a}_{\mathrm{w}}$ of tahini decreased.

\section{Introduction}

Tahini or sesame seed pastries are consumed widely in the Middle East and Eastern Mediterranean countries as a dip, salad dressing or as a main ingredient in many ready-to-eat foods such as halva and hummus (Osaili \& Al-Nabulsi, 2016). Tahini contains $57-65 \%$ fat, $23-27 \%$ protein, $6.4-9 \%$ carbohydrate and $1 \%$ moisture (Abu-Jdayil et al., 2002) and has a low water activity $\left(a_{w}\right)$ (average $a_{w}$ is 0.16 ) with a shelf life at room temperature of 1 year (Osaili et al., 2016). Tahini can pose a microbial risk to consumer heath as it has been involved in several salmonellosis outbreaks. In 2002 and 2003, imported tahini contaminated with Salmonella Montevideo was responsible for three outbreaks in New Zealand and Australia (Unicomb et al., 2005). In 2011, hummus and tahini contaminated with $S$. Bovismorbificans were associated with a multistate outbreak in the US (Centers for Disease Control and Prevention, 2012). Also, in 2013 an illness outbreak linked to Salmonella serovar contamination of tahini was documented in the US (Centers for Disease Control and Prevention, 2013). Recently, another two salmonellosis outbreaks linked to tahini which infected a total of 11 persons were reported in the US in 2018 and 2019 (Centers for Disease Control and Prevention, 2018, 2019).

The undercooked meat and meat products, particularly poultry products have been known as a major source of Salmonella serotypes; however, other food products such as fresh produce, dairy products, and low $\mathrm{a}_{\mathrm{w}}$ foods have been found to be contaminated with different Salmonella spp. (Beuchat et al., 2013;
Chávez-Martínez et al., 2019; Cruz et al., 2019; Cunha-Neto et al., 2019; Mendonça et al., 2019). Salmonella can be eliminated from foods by pasteurization of high $\mathrm{a}_{\mathrm{w}}$ foods such as liquid milk or juices (Beuchat et al., 2013) or using the microwave processing of low $a_{w}$ foods such as infant milk (Portela et al., 2019), which indicates the susceptibility of Salmonella to heat.

The basic operation in tahini production involves roasting of sesame seeds to enhance the color, flavor and texture as well as improve its palatability. The optimum roasting conditions to obtain the best texture and color of tahini ranges from 155 to $170^{\circ} \mathrm{C}$ for 40 to $60 \mathrm{~min}$ (Kahyaoglu \& Kaya, 2006). According to Torlak et al. (2013), Salmonella did not survive roasting of sesame seeds at 110,130 , and $150{ }^{\circ} \mathrm{C}$. However, Zhang et al. (2017) reported survival of Salmonella on sesame seeds increased as $\mathrm{a}_{\mathrm{w}}$ decreased during roasting. Thus, the presence of Salmonella in tahini might be due to the ability of Salmonella to survive the roasting process if the seeds are at a low $\mathrm{a}_{\mathrm{w}}$ at the beginning of the roasting process (Zhang et al., 2017), or their presence may be due to post-heat treatment contamination from equipment, workers or the processing environment (World Health Organization, 2008; Torlak et al., 2013).

Salmonella have the ability to survive in low $\mathrm{a}_{\mathrm{w}}$ products for long periods (Burnett et al., 2000; Farakos et al., 2013; Osaili et al., 2017). Their survival is influenced by food composition, temperature, as well as $\mathrm{a}_{\mathrm{w}}$ (Beuchat et al., 2013; Farakos et al., 2013; Osaili et al., 2017). Farakos et al. (2013) 
modeled the influence of storage temperature $\left(21\right.$ to $\left.80^{\circ} \mathrm{C}\right), \mathrm{a}_{\mathrm{w}}$ (0.19 to 0.54 ) and water mobility on the survival of Salmonella in low moisture food products. The researchers reported that $\mathrm{a}_{\mathrm{w}}$ affected the viability of Salmonella significantly, since Salmonella survival at $21{ }^{\circ} \mathrm{C}$ was greater at lower $\mathrm{a}_{\mathrm{w}}$ levels $(0.16$ and 0.26$)$ in comparison with higher $\mathrm{a}_{\mathrm{w}}$ levels (0.34 to 0.53$)$. A study conducted by Burnett et al. (2000) on products similar to tahini found that Salmonella had the ability to survive during storage in peanut butters and peanut butter spreads. The study also found that populations of $5.7 \log _{10} \mathrm{CFU} / \mathrm{g}$ decreased after 6 months at 21 and $5{ }^{\circ} \mathrm{C}$ by 4.1-4.5 $\log _{10} \mathrm{CFU} / \mathrm{g}$ and 2.9-4.3 $\log _{10} \mathrm{CFU} / \mathrm{g}$, respectively, depending on the formula composition. In a recent study, Osaili et al. (2017) reported that Salmonella serovar survival in halva decreased as storage temperature and time increased. After 1 year at 10 and $25^{\circ} \mathrm{C}$, Salmonella numbers decreased by 2.7 , and $5.2 \log _{10} \mathrm{CFU} / \mathrm{g}$, respectively.

Before contaminating food, microorganisms might be exposed to one or more environmental stresses, including desiccation, starvation, heat, cold, or different types of chemical agents in processing plant environments (Osaili et al., 2008a, b). Exposure of a microorganism to a stress may cross-protect the microbe against naïve stresses, and therefore boost its survival (Bunning et al., 1990; Abee \& Wouters, 1999). Exposing Salmonella serovars to heat or desiccation stress prior to inoculation extended their viability in halva during storage (Osaili et al., 2017).

As mentioned, $\mathrm{a}_{\mathrm{w}}$ value and temperature during storage interact to influence the viability of Salmonella in low $\mathrm{a}_{\mathrm{w}}$ food products. However, no studies were found on the effect of $a_{w}$ and storage temperature on the viability of Salmonella serovars in tahini, even though this microbe may behave differently if producers manipulate tahini $\mathrm{a}_{\mathrm{w}}$ and storage temperature. Thus, the objective of the current study was to examine the impact of increasing tahini $\mathrm{a}_{\mathrm{w}}$ from 0.17 to 0.35 or 0.50 and decreasing temperature from $25^{\circ} \mathrm{C}$ to $10{ }^{\circ} \mathrm{C}$ on the survival of inoculated Salmonella serovars. In addition, the current study assessed the effect of heat and desiccation stresses on the viability of Salmonella serovars in tahini during storage for one year.

\section{Materials and methods}

\subsection{Tahini samples}

Tahini samples of one brand with no additives were obtained from a local grocery store in Irbid, Jordan. The purchased samples were checked for the presence of Salmonella using an ISO method (International Organization for Standardization, 2002) and were found Salmonella free. The total mesophilic aerobic bacteria of tahini samples were determined by adding $10 \mathrm{~g}$ of tahini to $90 \mathrm{~mL}$ peptone water (Oxoid, Hampshire, UK) followed by vigorous mixing and serial 10 -fold serial dilution. Thereafter, $1 \mathrm{~mL}$ of the appropriate dilution was mixed with molten, tempered Plate Count Agar (Oxoid) using the pour plate technique and solidified plates were incubated at $35^{\circ} \mathrm{C}$ for $48 \mathrm{~h}$.

\subsection{Proximate analysis of Tahini}

AOAC methods (Association of Official Analytical Chemists, 1984) were used to determine carbohydrate, protein, fat, moisture and ash contents of tahini. The analyses were performed on triplicate samples and the average value of each component was determined.

\subsection{Water activity $\left(a_{w}\right)$}

The $\mathrm{a}_{\mathrm{w}}$ of tahini was determined at room temperature $\left(21 \pm 1^{\circ} \mathrm{C}\right.$ ) using an $\mathrm{a}_{\mathrm{w}}$ meter (Hygrolab, Rotronic Inst. Corp, Huntington, NY, US). The original $a_{w}$ value of the tahini samples was $0.17 \pm 0.01$. Then other samples of tahini were prepared and the $\mathrm{a}_{\mathrm{w}}$ values were adjusted to $0.35 \pm 0.01$ and $0.50 \pm 0.01$ by mixing tahini samples with sterile distilled water.

\subsection{Culture preparation}

Four serovars of Salmonella used in this study were previously isolated from commercial tahini from the local market (S. Cubana T123, S. Aberdeen T108, S. Typhimurium T069, and S. Paratyphi A T193) and were obtained from the Jordanian Food and Drug Administration. Fresh cultures were prepared from the frozen state by streaking a loopful of each culture onto selective medium (Xylose Lysine Deoxychocolate XLD agar) (Oxoid). The plates were incubated for $24 \mathrm{~h}$ at $37^{\circ} \mathrm{C}$. One typical colony from each isolate was grown individually in Tryptic Soy Broth (Oxoid) followed by $24 \mathrm{~h}$ incubation at $37^{\circ} \mathrm{C}$. Before beginning the experiments, three consecutive transfers were conducted to obtain an active culture to be used in the trials.

\subsection{Preparation of Salmonella serovar suspensions}

A $10 \mathrm{~mL}$ broth sample of freshly cultivated Salmonella was centrifuged at $4000 \mathrm{~g}$ for $15 \mathrm{~min}$ and the supernatant was discarded. The resulting pellets were mixed with $0.25 \mathrm{~mL}$ of sterile buffered peptone water (BPW). The suspension was mixed vigorously by means of a vortex mixer. The individually prepared suspensions of each Salmonella serovar were combined together to form a mixture of 4 Salmonella serovars with a final concentration of approximately $10^{9} \mathrm{CFU} / \mathrm{mL}$.

\subsection{Preparation of desiccation and heat-stressed Salmonella suspensions}

The mixture of Salmonella serovars was exposed to desiccation or heat stresses. Stresses were applied according to protocols published previously (Gruzdev et al., 2011; Osaili et al., 2016) with slight modifications to obtain a treatment condition that would result in no more than $1 \log _{10}$ reduction in bacterial numbers. Desiccated cells were prepared by dividing $1 \mathrm{~mL}$ of fresh Salmonella mixture into 40 portions of $25 \mu \mathrm{L}$ which were placed into a sterile Petri dish held in biosafety cabinet without a lid for $4 \mathrm{~h}$. Thereafter, the desiccated culture was rehydrated by adding $1 \mathrm{~mL}$ of BPW to the plate and the liquefied, desiccated culture was gently shaken and collected in a sterile test tube. For the preparation of heat-stressed Salmonella, a $15 \mathrm{~mL}$ screw-cap test tube containing $9 \mathrm{~mL}$ of $0.1 \mathrm{M}, \mathrm{pH} 6.8$ potassium phosphate buffer that had been heated to $50{ }^{\circ} \mathrm{C}$ in a shaking water bath was used. One $\mathrm{mL}$ of the Salmonella mixture was added to the buffer and kept for $10 \mathrm{~min}$ at $50{ }^{\circ} \mathrm{C}$. Thereafter, the tube was removed and cooled instantly using running tap water. Then the 
mixture was centrifuged for $15 \mathrm{~min}$ at $4000 \mathrm{~g}$. The supernatant was discarded and the pellet was remixed with $1 \mathrm{~mL}$ of BPW.

\subsection{Tahini inoculation}

Tahini samples (100 $\mathrm{g}$ with a levels of $0.17,0.35$ and 0.50 ) were inoculated with $0.2 \mathrm{~mL}$ of a freshly stressed or unstressed Salmonella serovar mixture to achieve an inoculation level of $10^{6}$ to $10^{7} \mathrm{CFU} / \mathrm{g}$. The inoculation procedure was tested and found to elicit no change in the $\mathrm{a}_{\mathrm{w}}$ value of the samples.

\subsection{Storage of the samples}

After thoroughly mixing tahini samples with the cultures, $10 \mathrm{~g}$ sub-samples were placed in sterile Stomacher bags. The bags were massaged manually to expel air, followed by heat sealing and storing at 10 or $25^{\circ} \mathrm{C}$ for up to 12 months.

\subsection{Bacterial enumeration}

Tahini samples inoculated with a stressed or unstressed Salmonella mixture were sampled at 0,1 and 2 weeks, and monthly for 12 months. All samples were serially diluted in $0.1 \%$ peptone water. The thin agar layer method was used to recover Salmonella survivors (Osaili et al., 2010). In this method, an appropriate dilution was spread-plated onto XLD overlaid with a thin layer of Tryptic Soy Agar (Oxoid) in duplicate to recover injured cells. The plates were incubated aerobically for 24 to $48 \mathrm{~h}$ at $37^{\circ} \mathrm{C}$.

\subsection{Statistical analysis}

All trials completed during this study were conducted in triplicate. Effects of stress type, storage temperature, time and $\mathrm{a}_{\mathrm{w}}$ on the survival of Salmonella in tahini were evaluated using SPSS version 19.0 (2009; Chicago, IL, US). To compare effects of the two temperatures a t-test was performed. The effects of $\mathrm{a}_{\mathrm{w}}$, stress type and storage time were examined using one-way ANOVA. To determine the difference between variables, the Duncan post-hoc test was performed. For statistical significance the cut-off level was based on a $P$-value of $<0.05$.

\section{Results}

\subsection{Proximate analysis and total plate count of Tahini}

Fat, protein, carbohydrate, ash and moisture contents of tahini samples were $58.12 \pm 0.71 \%, 24.86 \pm 0.17 \%, 13.52 \pm 0.86 \%$, $3.7 \% \pm 0.0$, and $0.04 \pm 0.01 \%$, respectively. The total bacterial plate count in tahini was $2.7 \pm 0.2 \log _{10} \mathrm{CFU} / \mathrm{g}$.

\subsection{Effect of storage temperature and time on the viability of stressed and unstressed Salmonella in Tahini}

The survival of unstressed, and desiccation or heat-stressed Salmonella serovars in tahini with $\mathrm{a}_{\mathrm{w}}$ of $0.17,0.35$ and 0.50 stored for up to 12 months at 10 and $25{ }^{\circ} \mathrm{C}$ is shown in Figures 1-3. Unstressed cells of Salmonella were able to survive well in tahini during storage at 10 and $25{ }^{\circ} \mathrm{C}$ for at least 12 and 9 months, respectively, regardless of $\mathrm{a}_{\mathrm{w}}$ level. The survival of both stressed

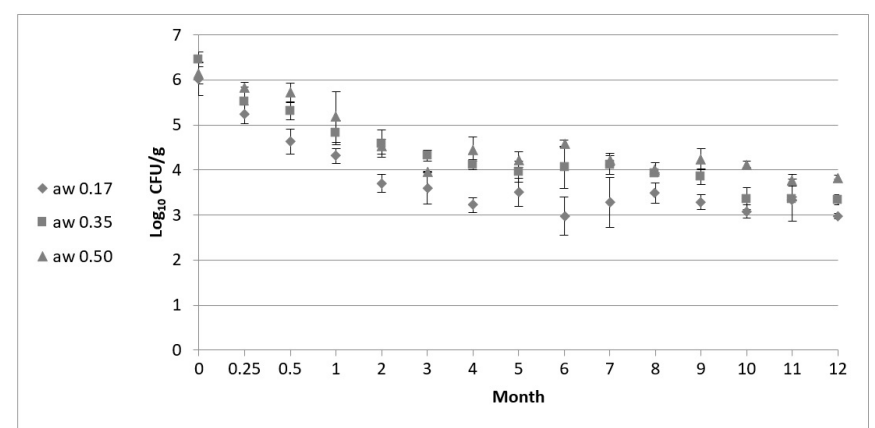

a)

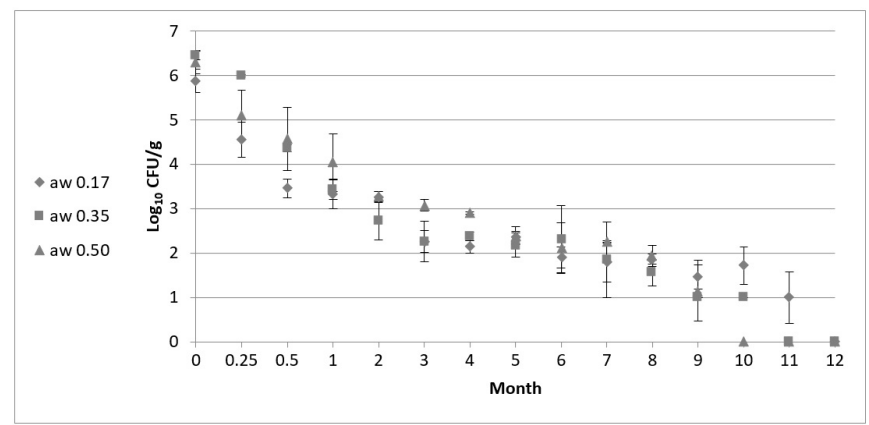

b)

Figure 1. Survival $\left(\log _{10} \mathrm{CFU} / \mathrm{g}\right.$ ) of unstressed (control) Salmonella spp. in tahini samples with different $\mathrm{a}_{\mathrm{w}}$ values $(0.17,0.35$ and 0.50$)$ during storage at (a) $10^{\circ} \mathrm{C}$ and (b) $25^{\circ} \mathrm{C}$ for up to 12 months. Values are represented as a mean of three replications \pm standard deviation. Detection limit $<10 \mathrm{CFU} / \mathrm{g}$.

and unstressed Salmonella in tahini decreased as the storage temperature, time and $\mathrm{a}_{\mathrm{w}}$ of tahini samples increased. Storage temperature had a significant $(P<0.05)$ effect on the viability of stressed and unstressed Salmonella in tahini regardless of storage time and $\mathrm{a}_{\mathrm{w}}$ value. At the same $\mathrm{a}_{\mathrm{w}}$ level, the viability of Salmonella in samples stored at $10^{\circ} \mathrm{C}$ was significantly $(P<0.05)$ higher than when stored at $25^{\circ} \mathrm{C}$. A significantly greater reduction in the number of unstressed Salmonella survivors was noticed after $14 \mathrm{~d}$ storage at $25^{\circ} \mathrm{C}$ compared to $10^{\circ} \mathrm{C}$ in samples with $\mathrm{a}_{\mathrm{w}}$ values of 0.17 and 0.35 but not at 0.50 . Yet, a significantly greater reduction was noticed at an $\mathrm{a}_{\mathrm{w}}$ of 0.5 after 2 months storage at $25^{\circ} \mathrm{C}$ compared to $10^{\circ} \mathrm{C}$. For desiccation-stressed cells (Figure 2), the impact of temperature on the survival of Salmonella was also influenced by $\mathrm{a}_{\mathrm{w}}$. At $25^{\circ} \mathrm{C}$ the extent of reduction was generally more pronounced than at $10^{\circ} \mathrm{C}$. The magnitude of reduction in Salmonella numbers at $25^{\circ} \mathrm{C}$ was significantly $(P<0.05)$ greater from 2 weeks until 10 months of storage than at $10^{\circ} \mathrm{C}$ when the $\mathrm{a}_{\mathrm{w}}$ was 0.17 and 0.35 . Also, the reduction was more pronounced during the initial storage period ( 2 weeks to 1 month) at an $\mathrm{a}_{\mathrm{w}}$ of 0.17 and 0.35 at the higher storage temperature.

The reduction in unstressed and stressed Salmonella survival was significant throughout storage irrespective of temperature and $\mathrm{a}_{\mathrm{w}}$ value of the samples. After 12 months at $10^{\circ} \mathrm{C}$, the viability of unstressed Salmonella in samples with $\mathrm{a}_{\mathrm{w}}$ values of $0.17,0.37$ and 0.50 decreased by $3.1,3.1$, and $2.3 \log _{10} \mathrm{~W} F U / g$, respectively, and became undetectable $(<10 \mathrm{CFU} / \mathrm{g})$ in samples stored at $25^{\circ} \mathrm{C}$. After 1 and 3 months at $25^{\circ} \mathrm{C}$, the number of desiccation or heat-stressed cells dropped by 2.5-3.3 and 3.2-3.7 $\log _{10} \mathrm{CFU} / \mathrm{g}$, 


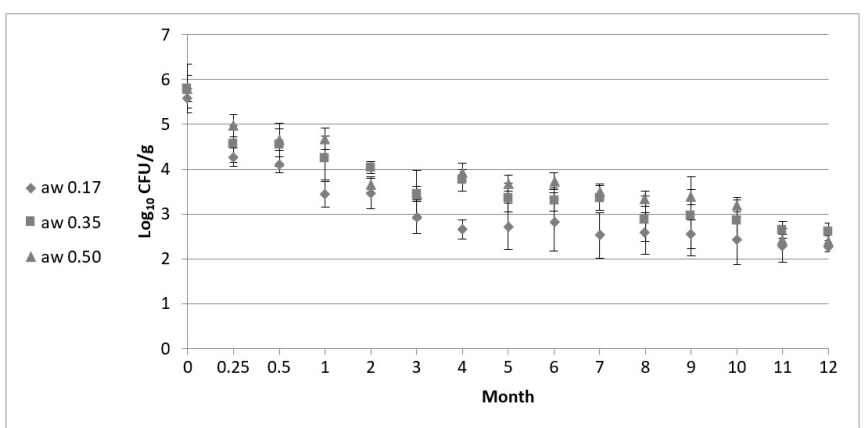

a)

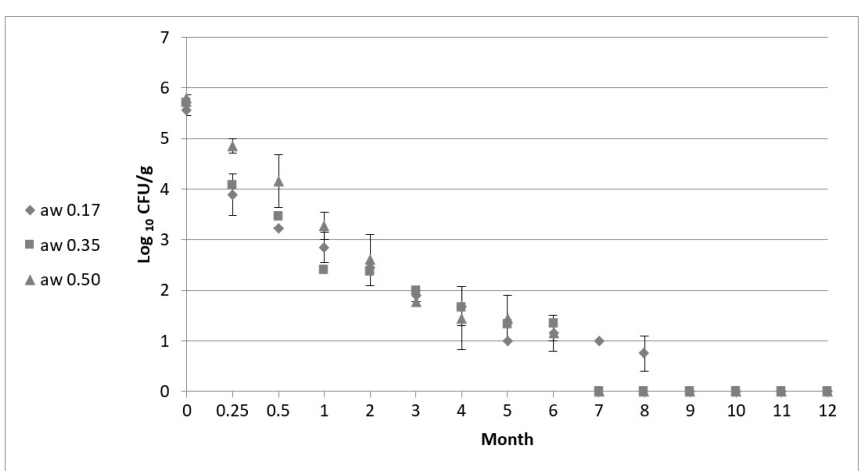

b)

Figure 2. Survival ( $\log _{10} \mathrm{CFU} / \mathrm{g}$ ) of desiccation-stressed Salmonella spp. in tahini samples with different $\mathrm{a}_{\mathrm{w}}$ values $(0.17,0.35$ and 0.50$)$ during storage at (a) $10{ }^{\circ} \mathrm{C}$ and (b) $25^{\circ} \mathrm{C}$ for up to 12 months. Values are represented as a mean of three replications \pm standard deviation. Detection limit $<10 \mathrm{CFU} / \mathrm{g}$.

respectively, compared with their initial numbers. However, the reduction of stressed cells was significantly lower in tahini stored at $10^{\circ} \mathrm{C}$ for the corresponding storage durations.

\subsection{Effect of $a_{w}$ on the viability of stressed and unstressed Salmonella in Tahini}

Survival of stressed or unstressed Salmonella serovars in samples with higher $a_{w}$ was greater than in those with lower $a_{w}$ during storage at $10^{\circ} \mathrm{C}$. The order of the $\mathrm{a}_{\mathrm{w}}$ effect on Salmonella reduction in samples was $0.17>0.35>0.50$ (Figures 1-3). In general, the effect of $\mathrm{a}_{\mathrm{w}}$ on the survival of stressed and unstressed Salmonella in tahini was more pronounced at $25^{\circ} \mathrm{C}$, in particular after 5 months of storage. Generally, there were no significant differences among the survival of unstressed Salmonella in samples with $\mathrm{a}_{\mathrm{w}}$ values of $0.17,0.35$ and 0.50 during the first 3 months of storage at either 10 or $25^{\circ} \mathrm{C}$. However, during 3-7 months storage at $10^{\circ} \mathrm{C}$, desiccation-stressed Salmonella showed a greater ability to survive at an $\mathrm{a}_{\mathrm{w}}$ of 0.50 than at 0.17 . In comparison, heat-stressed Salmonella cells exhibited greater survival at an $\mathrm{a}_{\mathrm{w}}$ of 0.50 than at 0.17 only during the first 4 months of storage at $10^{\circ} \mathrm{C}$.

\subsection{Effect of desiccation and heat stresses on the viability of Salmonella in Tahini}

There were significant differences $(P<0.05)$ between the survival of stressed Salmonella and unstressed cells during

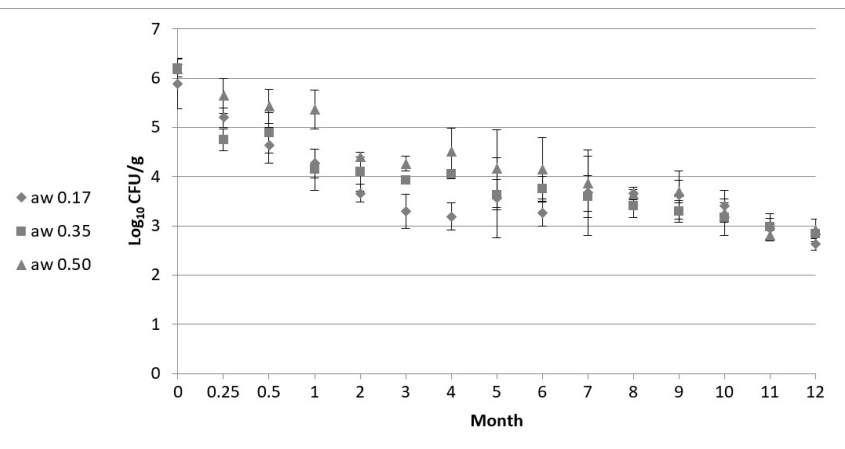

a)

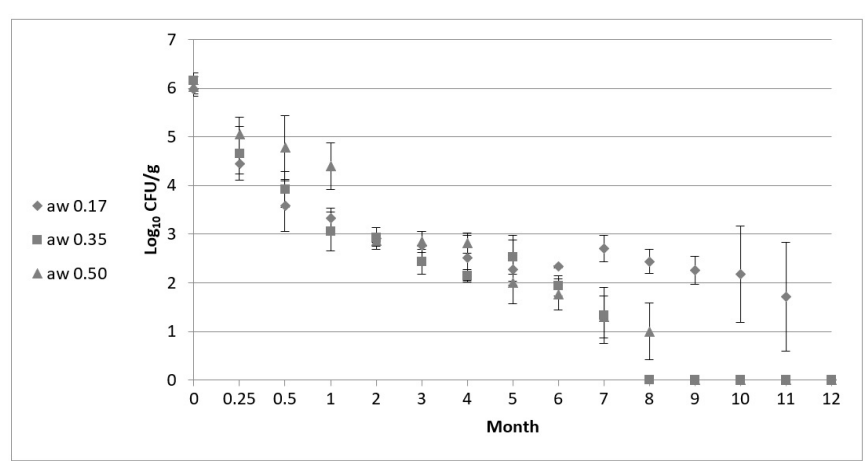

b)

Figure 3. Survival $\left(\log _{10} \mathrm{CFU} / \mathrm{g}\right)$ of heat-stressed Salmonella spp. in tahini samples with different $\mathrm{a}_{\mathrm{w}}$ values $(0.17,0.35$ and 0.50$)$ during storage at (a) $10{ }^{\circ} \mathrm{C}$ and (b) $25^{\circ} \mathrm{C}$ for up to 12 months. Values are represented as a mean of three replications \pm standard deviation. Detection limit $<10 \mathrm{CFU} / \mathrm{g}$.

storage of tahini with different $\mathrm{a}_{\mathrm{w}}$ values at 10 and $25^{\circ} \mathrm{C}$ for up to 12 months (Figures 1-3). At all $\mathrm{a}_{\mathrm{w}}$ levels, the survival of desiccation-stressed Salmonella was lower than that of unstressed or heat-stressed Salmonella cells. It was noted that survival of unstressed Salmonella decreased below the detection limit after 12,11 , and 10 months of storage at $25^{\circ} \mathrm{C}$ with $\mathrm{a}_{\mathrm{w}}$ values of 0.17 , 0.35 and 0.50 , respectively. Desiccation-stressed Salmonella reached undetectable levels after 7,7 , and 9 months of storage at $25^{\circ} \mathrm{C}$ in tahini with $\mathrm{a}_{\mathrm{w}}$ values of $0.50,0.35$ and 0.17 , respectively. For heat-stressed Salmonella, no cells were detectable after 8, 9, and 12 months storage at $25^{\circ} \mathrm{C}$ in tahini with a similar order of $\mathrm{a}_{\mathrm{w}}$ values.

\section{Discussion}

The observations made during the present study are in agreement with other reports. Osaili et al. (2017) reported that Salmonella survived in halva during storage for 1 year at 10 and $25^{\circ} \mathrm{C}$ and that their populations decreased significantly as storage temperature and time increased. Holliday et al. (2003) indicated that Salmonella serovars were able to survive well in fat spreads, and the reduction in the numbers was greater at $21{ }^{\circ} \mathrm{C}$ compared to 4 or $10{ }^{\circ} \mathrm{C}$. Similarly, Kotzekidou (1998) found that Salmonella survived better in halva after 8 months at $4{ }^{\circ} \mathrm{C}$ compared to room temperature storage. In addition, Burnett et al. (2000) reported Salmonella survived better in peanut butter when stored at $5{ }^{\circ} \mathrm{C}$ compared to $21^{\circ} \mathrm{C}$. They pointed out 
that the initial $5.7 \log _{10} \mathrm{CFU} / \mathrm{g}$ of Salmonella mixed culture in commercial peanut butter and peanut butter spreads decreased by 4.1-4.5 $\log _{10} \mathrm{CFU} / \mathrm{g}$ or 2.9-4.3 $\log _{10} \mathrm{CFU} / \mathrm{g}$ after storage for 6 months at 21 or $5{ }^{\circ} \mathrm{C}$, respectively. Also, it was reported that the reduction in $S$. Typhimurium and $E$. coli O157:H7 numbers was greater at $37^{\circ} \mathrm{C}$ than at $10^{\circ} \mathrm{C}$ during storage of tahini for $28 \mathrm{~d}$ (Al-Nabulsi et al., 2014, 2020). Kilonzo-Nthenge et al. (2009) reported that Salmonella and E. coli O157:H7 survived better in peanut butter stored at $25^{\circ} \mathrm{C}$ than in that stored at $4{ }^{\circ} \mathrm{C}$ for the same period. Similarly, the number of Salmonella viable in a mixed culture decreased during 4 months storage of tahini at 4 and $22{ }^{\circ} \mathrm{C}$ by 3.3 and $4.5 \log _{10} \mathrm{CFU} / \mathrm{g}$, respectively (Torlak et al., 2013). However, other reports revealed that Salmonella numbers in low $\mathrm{a}_{\mathrm{w}}$ products either did not change during storage or were not affected by storage temperature. Zhang et al. (2017) indicated that Salmonella can survive with no change in numbers in tahini during refrigerated storage for 4 months. Additionally, no significant differences were noticed between the levels of $S$. Tennessee in 4 of 5 commercial brands of peanut butter stored at 4 or $22^{\circ} \mathrm{C}$. The $S$. Tennessee viability dropped by 0.15 to 0.65 or 0.34 to $1.29 \log _{10} \mathrm{CFU} / \mathrm{g}$ in samples stored $14 \mathrm{~d}$ at 4 or $22^{\circ} \mathrm{C}$, respectively. In another study, the initial population of Salmonella inoculated on the shell of walnuts was reduced by $0.29 \log _{10}$ CFU per nut after the first $8 \mathrm{~d}$ storage at $10^{\circ} \mathrm{C}$ and an $\mathrm{RH}$ of $65 \%$ after drying, but no change in the population was noted after 3 months of storage (Frelka et al., 2016). Salmonella possess strategies to survive long times in a desiccated state. These survival strategies may include the accumulation of osmoprotectant molecules/metabolites, filamentation of cells, and switching to a metabolically dormant state (Finn et al., 2013). The variation between these and the results presented in the current study may have been due to serovar differences, variation in culture cultivation procedures, product composition or the variability in the storage time of the products that was mostly compatible with anticipated shelf-life of the product. In the studies by Zhang et al. (2017) and Frelka et al. (2016), bacteria used were taken from solid media and were sessile cells, while in the present study bacteria used were planktonic in nature, grown in liquid media. In addition, tahini samples used in the Zhang et al. (2017) study were prepared by grinding sesame seeds with olive oil in a food processor while commercial tahini samples were used in the present study.

In the current study, the reduction in Salmonella viability was more evident at $25^{\circ} \mathrm{C}$ than $10^{\circ} \mathrm{C}$. This might be explained by the observation that the fluidity of the cell membrane is enhanced as temperature increases, and this in turn, increases its permeability to phenolic compounds that abundantly exist in tahini and can exert an inhibitory effect against Salmonella (Al-Nabulsi \& Holley, 2006). Tahini is a colloidal suspension of lipid and water. It is possible that Salmonella in tahini would have a tendency to collect or localize within or around the water phase. In a study conducted by Burnett et al. (2000) it was stated that the survival of Salmonella in peanut butter is probably influenced by the droplet size of water and lipid distributed in the products, and droplet size and aggregation may increase throughout lengthy storage. A similar situation may happen in tahini where Salmonella viability is expected to differ in the primary stages of storage compared to later stages; depending on emulsion stability and water droplet sizes in tahini. However, additional studies are needed to explain the relationships among emulsion stability, droplet size and the survival of pathogens in an emulsion like tahini.

Water, a major constituent of food, is a vital element in growth/inactivation of microorganisms (Podolak et al., 2010). The cell-water interaction is described as $\mathrm{a}_{\mathrm{w}^{\text {. }}}$. In contrast to the present work, some studies have shown that reduced $\mathrm{a}_{\mathrm{w}}$ protects against the decrease of Salmonella serovars in low moisture food products (Archer et al., 1998; Doyle \& Mazzotta, 2000; Beuchat \& Scouten, 2002; Keller et al., 2013; Gradl et al., 2015). Gradl et al. (2015) and Keller et al. (2013) reported that Salmonella viability decreased during 25 and $37^{\circ} \mathrm{C}$ storage of ground ginger and black pepper when $\mathrm{a}_{\mathrm{w}}$ was about 0.86 , however, viability remained relatively stable when the $\mathrm{a}_{\mathrm{w}}$ of samples was $<0.40$. Similarly, Salmonella numbers decreased during 25 and $37^{\circ} \mathrm{C}$ storage on alfalfa seeds with an $\mathrm{a}_{\mathrm{w}}$ of 0.21 to 0.60 , but not when stored at $5{ }^{\circ} \mathrm{C}$, as the $\mathrm{a}_{\mathrm{w}}$ in seeds was increased (Beuchat \& Scouten, 2002). However, in agreement with the findings in the present study, Jung \& Beuchat (1999) stated that Salmonella strains survived in whole egg white and yolk powders with $\mathrm{a}_{\mathrm{w}}$ adjusted to $0.29-0.37$ and $0.51-0.61$ at 13 and $37^{\circ} \mathrm{C}$ during 8 weeks. The survival of different strains of Salmonella was greater at $\mathrm{a}_{\mathrm{w}}$ 0.51-0.61 than at 0.29-0.37. As noted earlier, differences between published results and those presented here may have arisen from differences in tested serovars, differences in their cultivation before inoculation, differences in tahini formulations, product $\mathrm{a}_{\mathrm{w}}$ values, test temperatures and intervals. In addition, sesame seeds contain the phytochemicals: lignan, sesamolin, sesamin, sesamol and methylene dioxyphenyl compounds (Kähkönen et al., 1999). A study on sesame by Mahendra Kumar \& Singh (2015) indicated that sesamol and lignans have antioxidant and antimicrobial effects, and roasted sesame oil contains a higher amount of sesamol. They also pointed out that when the concentrations of lignans and sesamol were increased, the viability of Pseudomonas aeruginosa, Staphylococcus aureus and Bacillus cereus decreased. Therefore, it is anticipated that a low $\mathrm{a}_{\mathrm{w}}$ of 0.17 and phenolic compounds will probably act synergistically to cause reductions of Salmonella serovars. Nonetheless, further investigation of the impact of low $\mathrm{a}_{\mathrm{w}}$ and the presence of antimicrobials in tahini is needed to confirm their effect upon the survival of Salmonella in tahini.

In the current study, unstressed Salmonella were capable of surviving better under different $\mathrm{a}_{\mathrm{w}}$ and storage temperatures compared to desiccation and heat-stressed Salmonella. On the contrary, Osaili et al. (2017) found that the survival of desiccation and heat-stressed Salmonella in halva samples was slightly greater $(P \geq 0.05)$ than that of unstressed cells stored at 10 and $25{ }^{\circ} \mathrm{C}$. It is worth noting that when stressed or unstressed Salmonella are inoculated into tahini they are exposed to additional desiccation stress in the product. In the current study, heat stress may cross-protect Salmonella against a low $\mathrm{a}_{\mathrm{w}}$ environment when stored in tahini with an $\mathrm{a}_{\mathrm{w}}$ of 0.17 at $25{ }^{\circ} \mathrm{C}$. In contrast to heat stress, desiccation stress reduced Salmonella viability as no cells were detected after 9 months. Salmonella might have been exposed to multiple stresses not only during preparation of desiccation-stressed cells, but also from the product itself during storage. In addition, microbial 
viability under desiccated conditions is mainly affected by the osmotic stress resistance of the microbe. Increased osmotic pressure by reducing $\mathrm{a}_{\mathrm{w}}$ affects microbial survival by inducing shrinkage and plasmolysis, inhibits DNA replication, nutrient uptake of bacteria and cell growth (Csonka, 1989).

\section{Conclusion}

The present study indicates that unstressed or desiccation or heat-stressed Salmonella can survive in tahini with different $a_{w}$ values for the entire12 month product shelf-life when kept at $10{ }^{\circ} \mathrm{C}$. Storage temperature has a remarkable effect on the survival of Salmonella in tahini. Unstressed Salmonella possessed better survival compared to desiccation and heat-stressed Salmonella at the same storage temperatures. Additionally, the survival of unstressed and stressed Salmonella was greater at $10{ }^{\circ} \mathrm{C}$ compared to $25^{\circ} \mathrm{C}$. A higher tahini $\mathrm{a}_{\mathrm{w}}$ of 0.50 resulted in greater Salmonella survival compared to when its $\mathrm{a}_{\mathrm{w}}$ was low ( 0.17 or 0.35 ), particularly at $10^{\circ} \mathrm{C}$.

\section{Acknowledgements}

This project was funded by the Deanship of Scientific Research at Jordan University of Science and Technology.

\section{References}

Abee, T., \& Wouters, J. A. (1999). Microbial stress response in minimal processing. International Journal of Food Microbiology, 50(1-2), 65-91. http://dx.doi.org/10.1016/S0168-1605(99)00078-1. PMid:10488845.

Abu-Jdayil, B., Al-Malah, K., \& Asoud, H. (2002). Rheological characterization of milled sesame (tehineh). Food Hydrocolloids, 16(1), 55-61. http://dx.doi.org/10.1016/S0268-005X(01)00040-6.

Al-Nabulsi, A. A., \& Holley, R. A. (2006). Enhancing the antimicrobial effects of bovine lactoferrin against Escherichia coli O157:H7 by cation chelation, $\mathrm{NaCl}$ and temperature. Journal of Applied Microbiology, 100(2), 244-255. http://dx.doi.org/10.1111/j.1365-2672.2005.02785.x. PMid:16430500.

Al-Nabulsi, A. A., Olaimat, A. N., Osaili, T. M., Shaker, R. R., Zein Elabedeen, N., Jaradat, Z. W., Abushelaibi, A., \& Holley, R. A. (2014). Use of acetic and citric acids to control Salmonella Typhimurium in tahini (sesame paste). Food Microbiology, 42, 102-108. http://dx.doi. org/10.1016/j.fm.2014.02.020. PMid:24929724.

Al-Nabulsi, A. A., Osaili, T. M., Olaimat, A. N., Almasri, W. E., AlHoly, M. A., Jaradat, Z. W., Ayyash, M., Awaisheh, S. S., \& Holley, R. A. (2020). Inhibitory effects of thyme and cinnamon essential oils against E. coli O157:H7 in Tahini. Food Science and Technology. http://dx.doi.org/10.1590/fst.21619.

Archer, J., Jervis, E., Bird, J., \& Gaze, J. (1998). Heat resistance of Salmonella Weltevreden in low-moisture environments. Journal of Food Protection, 61(8), 969-973. http://dx.doi.org/10.4315/0362028X-61.8.969. PMid:9713756.

Association of Official Analytical Chemists - AOAC. (1984). Official methods of analysis (14th ed.). Washington: AOAC.

Beuchat, L. R., \& Scouten, A. J. (2002). Combined effects of water activity, temperature and chemical treatments on the survival of Salmonella and Escherichia coli O157:H7 on alfalfa seeds. Journal of Applied Microbiology, 92(3), 382-395. http://dx.doi.org/10.1046/j.13652672.2002.01532.x. PMid:11872113.
Beuchat, L. R., Komitopoulou, E., Beckers, H., Betts, R. P., Bourdichon, F., Fanning, S., Joosten, H. M., \& Ter Kuile, B. H. (2013). Lowwater activity foods: increased concern as vehicles of foodborne pathogens. Journal of Food Protection, 76(1), 150-172. http://dx.doi. org/10.4315/0362-028X.JFP-12-211. PMid:23317872.

Bunning, V. K., Crawford, R. G., Tierney, J. T., \& Peeler, J. T. (1990). Thermotolerance of Listeria monocytogenes and Salmonella Typhimurium after sublethal heat shock. Applied and Environmental Microbiology, 56(10), 3216-3219. http://dx.doi.org/10.1128/AEM.56.10.32163219.1990. PMid:2126703.

Burnett, S. L., Gehm, E. R., Weissinger, W. R., \& Beuchat, L. R. (2000). Survival of Salmonella in peanut butter and peanut butter spread. Journal of Applied Microbiology, 89(3), 472-477. http://dx.doi. org/10.1046/j.1365-2672.2000.01138.x. PMid:11021579.

Centers for Disease Control and Prevention - CDC. (2012). Multistate outbreak of Salmonella serotype Bovismorbificans infections associated with hummus and tahini - United States, 2011. Atlanta: CDC. Retrieved from http://www.cdc.gov/mmwr/preview/mmwrhtml/mm6146a3.htm

Centers for Disease Control and Prevention - CDC. (2013). Salmonella Montevideo and Salmonella Mbandaka infections linked to Tahini sesame paste. Atlanta: CDC. Retrieved from http://www.cdc.gov/ salmonella/montevideo-tahini-05-13/

Centers for Disease Control and Prevention - CDC. (2018). Outbreak of Salmonella infections linked to Tahini from Achdut Ltd. Atlanta: CDC. Retrieved from https://www.cdc.gov/salmonella/concord-11-18/index.html

Centers for Disease Control and Prevention - CDC. (2019). Outbreak of Salmonella infections linked to Karawan brand tahini paste. Atlanta: CDC. Retrieved from https://www.cdc.gov/salmonella/ concord-05-19/index.html

Chávez-Martínez, A., Paredes-Montoya, P., Rentería-Monterrubio, A.-L., Corral-Luna, A., Lechuga-Valles, R., Dominguez-Viveros, J., Sánchez-Vega, R., \& Santellano-Estrada, E. (2019). Microbial quality and prevalence of foodborne pathogens of cheeses commercialized at different retail points in Mexico. Food Science and Technology, 39(Suppl. 2), 703-710. http://dx.doi.org/10.1590/fst.30618.

Cruz, M. R. G., Leite, Y. J. B. S., Marques, J. L., Pavelquesi, S. L. S., Oliveira, L. R. A., Silva, I. C. R., \& Orsi, D. C. (2019). Microbiological quality of minimally processed vegetables commercialized in Brasilia, DF, Brazil. Food Science and Technology, 39(Suppl. 2), 498-503. http:// dx.doi.org/10.1590/fst.16018.

Csonka, L. N. (1989). Physiological and genetic responses of bacteria to osmotic-stress. Microbiological Reviews, 53(1), 121-147. http:// dx.doi.org/10.1128/MMBR.53.1.121-147.1989. PMid:2651863.

Cunha-Neto, D. A., Carvalho, L. A., Castro, V. S., Barcelos, F. G., Carvalho, R. C. T., Rodrigues, D. P., Conte-Junior, C. A., \& Figueiredo, E. E. S. (2019). Salmonella Anatum, S. Infantis and S. Schwarzengrund in Brazilian Cheeses: occurrence and antibiotic resistance profiles. International Journal of Dairy Technology, 73(1), 296-300. http:// dx.doi.org/10.1111/1471-0307.12636.

Doyle, M. E., \& Mazzotta, A. S. (2000). Review of studies on the thermal resistance of Salmonellae. Journal of Food Protection, 63(6), 779-795. http://dx.doi.org/10.4315/0362-028X-63.6.779. PMid:10852574.

Farakos, S. M., Frank, J. F., \& Schaffner, D. W. (2013). Modeling the influence of temperature, water activity and water mobility on the persistence of Salmonella in low-moisture foods. International Journal of Food Microbiology, 166(2), 280-293. http://dx.doi.org/10.1016/j. ijfoodmicro.2013.07.007. PMid:23973840.

Finn, S., Condell, O., McClure, P., Amézquita, A., \& Fanning, S. (2013). Mechanisms of survival, responses, and sources of Salmonella in low-moisture environments. Frontiers in Microbiology, 4, 331. http:// dx.doi.org/10.3389/fmicb.2013.00331. PMid:24294212. 
Frelka, J. C., Davidson, G. R., \& Harris, L. J. (2016). Changes in aerobic plate and Escherichia coli-coliform counts and in populations of inoculated foodborne pathogens on in shell walnuts during storage. Journal of Food Protection, 79(7), 1143-1153. http://dx.doi. org/10.4315/0362-028X.JFP-15-553. PMid:27357033.

Gradl, D. R., Sun, L., Larkin, E. L., Chirtel, S. J., \& Keller, S. E. (2015). Survival of Salmonella during drying of fresh ginger root (Zingiberofficinale) and storage of ground ginger. Journal of Food Protection, 78(11), 1954-1959. http://dx.doi.org/10.4315/0362-028X. JFP-15-153. PMid:26555517.

Gruzdev, N., Pinto, R., \& Sela, S. (2011). Effect of desiccation on tolerance of Salmonella enterica to multiple stresses. Applied and Environmental Microbiology, 77(5), 1667-1673. http://dx.doi. org/10.1128/AEM.02156-10. PMid:21216905.

Holliday, S. L., Adler, B. B., \& Beuchat, L. R. (2003). Viability of Salmonella, Escherichia coli O157:H7, and Listeria monocytogenes in butter, yellow fat spreads, and margarine as affected by temperature and physical abuse. Food Microbiology, 20(2), 159-168. http://dx.doi. org/10.1016/S0740-0020(02)00127-2. PMid:12696676.

International Organization for Standardization - ISO. (2002). Microbiology of food and animal feeding stuffs: horizontal method for the detection of Salmonella spp. Geneva: ISO.

Jung, Y. S., \& Beuchat, L. R. (1999). Survival of multidrug-resistant Salmonella typhimurium DT104 in egg powders as affected by water activity and temperature. International Journal of Food Microbiology, 49(1-2), 1-8. http://dx.doi.org/10.1016/S0168-1605(99)00013-6. PMid:10477064.

Kähkönen, M. P., Hopia, A. I., Vuorela, H. J., Rauha, J. P., Pihlaja, K., Kujala, T. S., \& Heinonen, M. (1999). Antioxidant activity of plant extracts containing phenolic compounds. Journal of Agricultural and Food Chemistry, 47(10), 3954-3962. http://dx.doi.org/10.1021/ jf990146l. PMid:10552749.

Kahyaoglu, T., \& Kaya, S. (2006). Determination of optimum processing conditions for hot air roasting of hulled sesame seeds using response surface methodology. Journal of the Science of Food and Agriculture, 86(10), 1452-1459. http://dx.doi.org/10.1002/jsfa.2509.

Keller, S. E., Van Doren, J. M., Grasso, E. M., \& Halik, L. A. (2013). Growth and survival of Salmonella in ground black pepper (Piper nigrum). Food Microbiology, 34(1), 182-188. http://dx.doi.org/10.1016/j. fm.2012.12.002. PMid:23498196.

Kilonzo-Nthenge, A., Rotich, E., Godwin, S., \& Huang, T. (2009). Consumer storage period and temperature for peanut butter and their effects on survival of Salmonella and Escherichia coli O157:H7. Food Protection Trends, 29, 787-792.

Kotzekidou, P. (1998). Microbial stability and fate of Salmonella Enteritidis in halva, a low-moisture confection. Journal of Food Protection, 61(2), 181-185. http://dx.doi.org/10.4315/0362-028X-61.2.181. PMid:9708278.

Mahendra Kumar, C., \& Singh, S. A. (2015). Bioactive lignans from sesame (Sesamum indicum L.): evaluation of their antioxidant and antibacterial effects for food applications. Journal of Food Science and Technology, 52(5), 2934-2941. http://dx.doi.org/10.1007/s13197014-1334-6. PMid:25892793.

Mendonça, J. F. M., Vieira, F. O., Fonseca, I., Ribeiro, J. B., Arcuri, E. F., Borges, M. F., Borges, C. A. V., Sá, J. F. O., \& Martins, M. F. (2019). Detection of viable Salmonella Typhimurium and Staphylococcus aureus in Coalho cheese by Real-Time PCR. Food Science and Technology, 39(Suppl. 2), 690-696. http://dx.doi.org/10.1590/fst.29318.
Osaili, T. M., \& Al-Nabulsi, A. A. (2016). Inactivation of stressed Escherichia coli O157:H7 in Tahini (sesame seed paste) by ionization radiation. Food Control, 69, 221-226. http://dx.doi.org/10.1016/j. foodcont.2016.05.009.

Osaili, T. M., Al-Nabulsi, A. A., Abubakar, S. A., Alaboudi, A. R., \& Al-Holy, M. A. (2016). Feasibility of using gamma irradiation for inactivating of starvation, heat and cold stressed Salmonella in tahini. Journal of Food Protection, 79(6), 963-969. http://dx.doi. org/10.4315/0362-028X.JFP-15-495. PMid:27296600.

Osaili, T. M., Al-Nabulsi, A. A., Nazzal, D. S., \& Shaker, R. R. (2017). Effect of storage temperatures and stresses on the survival of Salmonella spp. in halva. Letters in Applied Microbiology, 65(5), 403-409. http:// dx.doi.org/10.1111/lam.12791. PMid:28802055.

Osaili, T. M., Al-Nabulsi, A. A., Shaker, R. R., Al-Holy, M. M., Al-Haddaq, M. S., Olaimat, A. N., Ayyash, M. M., Al Ta’Ani, M. K., \& Forsythe, S. J. (2010). Efficacy of the thin agar layer method for the recovery of stressed Cronobacter spp. (Enterobacter sakazakii). Journal of Food Protection, 73(10), 1913-1918. http://dx.doi.org/10.4315/0362028X-73.10.1913. PMid:21067681.

Osaili, T. M., Shaker, R. R., Abu Al-Hassan, A. S., Ayyash, M. M., \& Forsythe, S. J. (2008a). Effect of desiccation, starvation, heat and cold stresses on the thermal resistance of Enterobacter sakazakii in rehydrated infant milk formula. Journal of Food Science, 73(7), M354-M359. http://dx.doi.org/10.1111/j.1750-3841.2008.00880.x. PMid:18803719.

Osaili, T. M., Shaker, R. R., Olaimat, A. N., Al-Nabulsi, A. A., Al-Holy, M. M., \& Forsythe, S. J. (2008b). Detergent and sanitizer stresses decrease the thermal resistance of Enterobacter sakazakii in infant milk formula. Journal of Food Science, 73(3), M154-M157. http:// dx.doi.org/10.1111/j.1750-3841.2008.00671.x. PMid:18387119.

Podolak, R., Enache, E., Stone, W., Black, D. G., \& Elliott, P. H. (2010). Sources and risk factors for contamination, survival, persistence, and heat resistance of Salmonella in low-moisture foods. Journal of Food Protection, 73(10), 1919-1936. http://dx.doi.org/10.4315/0362028X-73.10.1919. PMid:21067682.

Portela, J. B., Coimbra, P. T., Cappato, L. P., Alvarenga, V. O., Oliveira, R. B. A., Pereira, K. S., Azeredo, D. R. P., Sant'Ana, A. S., Nascimento, J. S., \& Cruz, A. G. (2019). Predictive model for inactivation of Salmonella in infant formula during microwave heating processing. Food Control, 104, 308-312. http://dx.doi.org/10.1016/j.foodcont.2019.05.006.

Torlak, E., Sert, D., \& Serin, P. (2013). Fate of Salmonella during sesame seeds roasting and storage of tahini. International Journal of Food Microbiology, 163(2-3), 214-217. http://dx.doi.org/10.1016/j. ijfoodmicro.2013.03.010. PMid:23562834.

Unicomb, L. E., Simmons, G., Merritt, T., Gregory, J., Nicol, C., Jelfs, P., Kirk, M., Tan, A., Thomson, R., Adamopoulos, J., Little, C. L., Currie, A., \& Dalton, C. B. (2005). Sesame seed products contaminated with Salmonella: three outbreaks associated with tahini. Epidemiology and Infection, 133(6), 1065-1072. http://dx.doi. org/10.1017/S0950268805004085. PMid:16274503.

World Health Organization - WHO. (2008). Hazard analysis and critical control point generic models for some traditional foods: a manual for the eastern Mediterranean region. Geneva: WHO Regional Office for the Eastern Mediterranean Centre for Environmental Health Activities. Retrieved from http://apps.who.int/iris/bitstream/10665/119885/1/ dsa1100.pdf

Zhang, Y., Keller, S. E., \& Grasso-Kelley, E. M. (2017). Fate of Salmonella throughout production and refrigerated storage of tahini. Journal of Food Protection, 80(6), 940-946. http://dx.doi.org/10.4315/0362028X.JFP-16-507. PMid:28463084. 